\title{
Elektrisitetens velsignelser
}

\author{
I Tidsskriftet nr. 8/1933 gjøres det rede for en behandlingsmetode for isjias som ifølge forfatteren «synes \\ å ha avkortet sykdomsforløpet ganske betraktelig og meget snart fremkaller en betydelig nedsettelse av \\ smertene». Kort fortalt: Pasienten skulle ligge med en elektrisk lampe under dynen «slik at lys og varme \\ stråler direkte inn på den blottede legemsdel». Siden dette ga bedre resultat enn bruk av «de kostbare elek- \\ triske varmeputer», var han av den oppfatning at lyseffekten var vel så viktig som varmen. For å hindre brann \\ konstruerte han «et ganske simpelt «trepenal» med tynne spiler til beskyttelse - slik at strålen uhindret \\ slipper igjennem og sengklærne er sikret mot «svimerker» like så vel som patienten». Under følger en \\ arbeidsbeskrivelse (Tidsskr Nor Lægeforen 1933; 53: 404-6).
}

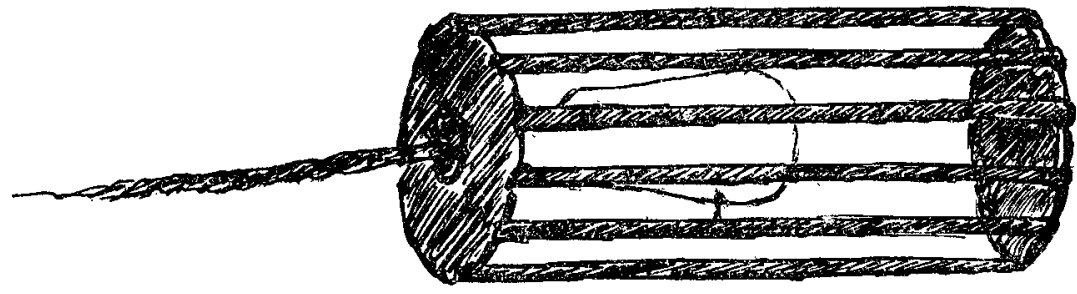

\section{Ischias.}

Av dagliglivets terapi.

Av P. Bretteville-Jensen, Sarpsborg.

Man bør også passe på at lampen er skrudd tålig godt fast i det ene endestykke, så den ikke kan falle ned mellem spilene. Om apparatet er litt større eller mindre spiller liten rolle. Vanligst har jeg latt gjøre dem 25 til $30 \mathrm{~cm}$. lange og 13-15 cm. i diameter. Cigarkassetre er i tynneste laget. Helst bør man velge et noget solidere stoff - fra en liten tynn kasse eller lignende. Enkelte har tatt det så høitidelig at de har latt en virkelig snekker utføre arbeidet; men de alle fleste har meget lettvint spikret den sammen selv med tynne stifter.

Jeg tillater mig å vedlegge et litet riss av et slikt "penal». En av «konstruktørene» har forbedret det ved å skjære ut en liten sektor, som kan klippes op og festes med små kastekroker for lettere å komme til lampen, hvis den skal skrues fastere eller skiftes med en sterkere. De fleste tåler godt en 24 til 32 lys lampe.

Kanskje har andre kolleger konstruert sig noget lignende - eller et ennu bedre apparat. Men da jeg ikke har sett det omtalt - så vidt jeg husker - har jeg tillatt mig å gjøre rede for mitt eget, fordi jeg tror at mangen praktikus vil ha glede av å forsøke det og at mange ischiaspatienter som er avskåret fra å få en mere fullkommen behandling, vil bli takknemmelige. Om post eller propter kan der jo alltid diskuteres, og prognosen ved en ischias "quoad durationem» er jo i det enkelte tilfelle alltid helt uviss; men å prøve apparatet i den daglige praksis kan ingen skade gjøre, og efter en mangeårig erfaring tror jeg, jeg tør si det har stått sin prøve, har lindret smerter, avkortet sykdomsforløpet og gjort patientene arbeidsdyktige adskillig før enn de ellers vilde kunne gjort sig håp derom. 